\title{
Effect of Different Mulch Treatments on Growth and Forage Yield of Millet (Pennicitum Americanum L.) Under Arid Land Conditions
}

\author{
Saeed. M. J. Turkustani, Hussain. E. Osman and Mohammed. H. Almarshadi \\ Arid Land Agriculture Department, \\ Faculty of Meteorology, Environment and Arid Land Agriculture, \\ King Abdulaziz University
}

\begin{abstract}
In this study soil was covered with wheat straw in four rates $(0,10,20$ and $30 \mathrm{t} / \mathrm{ha})$ to investigate effect of soil covering on growth and forage yield of millet (Pennicitum americanum L.) during two season spring and autumn of 2009. The results showed significant differences between the three growth stages (vegetative, flowering and fruiting stages) (different cutting periods) in all millet plant parameters (plant height, branch number, leaf area, fresh and dry forage yield and its components) studied during spring and autumn seasons. As for wheat straw covering treatments the results showed significant differences in the total millet fresh weight and its components stem and leaves in addition to plant height during spring, but for autumn season the results indicated significant differences between treatments in stem fresh weight and plant height. There is also significant interaction between cuttings and treatments for the total fresh weight, fresh weight of leaves and plant height during spring, with no significant interaction between cuttings and treatments during autumn season. Covering the soil with wheat straw have positive effects on growth parameters of millet crop.
\end{abstract}

Key words: Millet (Pennicitum americanum L.), wheat straw

\section{INTRODUCTION}

van Donk et al. 2008 conducted an experiment to study the effect of covering the soil with residue on soil water content and corn yield at North Platte, Nebraska. Mean corn yield was $12.4 \mathrm{Mg}$ ha-1 in the residue-covered plots, significantly greater than the bare-soil plots. Sinkevičienè et al. 2009 studied effect of covering soil with chopped wheat straw; peat; sawdust and grass on soil properties and crop yield. They found mulching significantly decreased soil temperature, and significantly raised soil moisture content throughout the experimental period, and the highest soil moisture content was in plots mulched with peat or sawdust. They also noticed higher amount of available phosphorus in the mulched soil plots, and also available potassium in the soil covered with grass. Also they detected mulching decreased weed density, and the grass-mulched plots significantly gave the highest crop yields. Soil mulching controls weed growth as weed is an important factor determining crop yields, (Bilalis et al., 2002; Radics \& Bognar, 2004; Jodaugiene et al., 2006). Evaporation of water from soil can be reduced by covering soil with plant residues, and also soil temperature will be stable (Ji \& Unger, 2001;
Kar \& Kumar, 2007). Sønsteby et al. 2004 mulched soil plots with wood chips and found significant increase in amounts of phosphorus and potassium levels in the leaves of the crop. They suggested that these nutrients have been released from decomposing mulches. (Sharma \& Sharma, 2003; Singh et al., 2007) stated that soil mulching improves plant growth and yield. Gruber et al. (2008), found no effect of mulching with wood chips on crop yield. Kar \& Kumar (2007) obtained higher potato yield and better crop growth were observed in plots with straw mulch, but (Johnson et al., 2004 and Döring et al. 2005) found that potato yields were similar in mulched and unmulched plots with no effect on mulching on potato yield. Zhang et al. 2015 evaluated the effects of mulching with various straw mulches on soil water content, grain yield, and water use efficiency (WUE) of winter wheat (Triticum aestivum), using three straw mulch rates; 3, 6 and $9 \mathrm{t} / \mathrm{ha}$. the average soil water content in the $0-200 \mathrm{~cm}$ soil layer increased significantly by $0.7-22.5 \%$ WUE by $30.6 \%, 32.7 \%$ and $24.2 \%$ the yield by $13.3-23.0 \%$ with 3,6 and $9 \mathrm{t} /$ ha respectively $(\mathrm{P}<0.05)$ compared to unmulched soil. Unger (1978) and Wicks et al.(1994) suggested that different amounts of straw mulch can have various effects on the yield, and that the crop yield is only increased with mulch amounts within certain ranges. Hares et al. 1992) showed that the inhibitory effect of straw mulch on soil evaporation with winter wheat could reach $63.2 \%$, while Zhao et al.1996 found that the inhibitory rate of straw mulch during wheat growth period was $21.5 \%$. Many studies have found that inappropriate mulching amounts can have negative effects, resulting in yield reductions (Gao and $\mathrm{Li}, 2005$ ). Wicks et al.(1994) suggested that different amounts of straw mulch can have various effects on the yield, and that the crop yield is only increased with mulch amounts within certain ranges. Cook et al.(2006) also reported that a wheat straw mulch at a rate of $2000-4000 \mathrm{~kg}$ ha-1 increased the maize yield, whereas a straw mulch of $6000-8000 \mathrm{~kg}$ ha-1 greatly decreased maize production.

\section{MATERIALS AND METHODS}

Preparation of plots:

The experiment was conducted at the Agricultural Research Station of King Abdulaziz University at Hada Alsham north east of Jeddah, Saudi Arabia. The site was ploughed with 
chiezel plough levelled and divided into 16 plots each 25 square meters $(5 \times 5 \mathrm{~m})$. The design used was complete randomized design with 4 replicates. The first season plantation was carried out in 20/3/2009 (spring) and the second in 20/9/2009 (autumn). Plots were divided into rows $15 \mathrm{~cm}$ apart, and millet was planted at rate of $25 \mathrm{~kg} / \mathrm{ha}$.

Fertilization:

Before planting potassium sulphate (K2 SO4) and super phosphate (P2 O5) was added at rate of $140 \mathrm{~kg} /$ ha as one dose, while nitrogen was added at 4 doses the first one after 15 days from planting and the last after 60 days from planting. Wheat straw covering was added after 3 weeks from germination, at rate of $0,25,50$ and $75 \mathrm{~kg} /$ plot equivalent to $(0,10,20$ and $30 \mathrm{t} / \mathrm{ha})$.

Climate of the study area:

Saudi Arabia is one of the driest countries in the world, with extremely low rainfall average per year. Climatic condition data of the study area (maximum, minimum, and means) of air temperature, relative humidity during the two crop seasons 2009 (spring and autumn) were collected from the meteorological station of Faculty of Meteorology, Environment, and Arid Land Agriculture at Hada Al-Sham Agricultural Research Station (Table 1 and 2).

TABLE (1) CLIMATE DATA OF THE STUDY AREA FOR SPRING SEASONS 2009.

\begin{tabular}{|c|c|c|c|c|c|c|}
\hline \multirow{2}{*}{ month } & \multicolumn{3}{|c|}{ Temperature degree $\mathbf{0}^{\mathbf{C}}$} & \multicolumn{3}{c|}{ Relative humidity (\%) } \\
\cline { 2 - 6 } & minimum & maximum & mean & 19 & maximum & 98 \\
\hline Mar & 14.8 & 37.4 & 18.7 & 20 & 97 \\
\hline April & 14.5 & 41.3 & 35.15 & 23 & 97 \\
\hline May & 15.8 & 46.4 & 39 & 21 & 91.5 & 95 \\
\hline
\end{tabular}

TABLE (2) CLIMATE DATA OF THE STUDY AREA FOR AUTUMN SEASONS 2009.

\begin{tabular}{|c|c|c|c|c|c|c|}
\hline \multirow{2}{*}{ month } & \multicolumn{3}{|c|}{ Temperature degree ${ }^{\mathbf{0}} \mathbf{C}$} & \multicolumn{3}{c|}{ Relative humidity (\%) } \\
\cline { 2 - 6 } & minimum & maximum & mean & minimum & maximum & 98 \\
\hline September & 19.2 & 44.2 & 41.3 & 24 & 93 & 99 \\
\hline October & 19 & 41.1 & 39.5 & 20 & 98 \\
\hline November & 17.5 & 35.4 & 35.2 & 29 & 98 \\
\hline Disambir & 13.3 & 32.3 & 29.5 & 26 & 97 & 59 \\
\hline
\end{tabular}

\section{Data collection:}

Plants were cut through three growth stages (vegetative, flowering and fruiting stages), and plants were removed from an area of 1 square meter inside each plot, for determination of the different parameters.

Statistical Analysis:

Factorial analysis for analysis of variance with SAS to compare between the different treatments, and also between different growth stages. Also interactions between treatments were analyzed.

\section{RESULTS}

Plant height $(\mathrm{cm})$ :

Results of the analysis of variance (table 3 ) show significant differences between wheat straw covering treatments in plant height during the three cutting periods (at vegetative, flowering and fruit growth) and also between cutting periods during both seasons autumn and spring. The average plant height ranged between $129 \mathrm{~cm}$ in the 1 st treatment and 160 $\mathrm{cm}$ in the second treatment during spring, and between 168 $\mathrm{cm}$ in the $3 \mathrm{rd}$ treatment and $210 \mathrm{~cm}$ in the 2 nd treatment during autumn season (table 4) with domination of autumn season in plant height compared to spring season (table 4). As for cutting periods the lowest plant height was attained in the 1 st cutting with $98 \mathrm{~cm}$ and $140 \mathrm{~cm}$, and the highest plant height was during the 3rd cutting with $186 \mathrm{~cm}$ and $210 \mathrm{~cm}$ for spring and autumn seasons respectively, with domination of autumn season in plant height compared to spring season (table 4).

\section{Number of stem branches:}

The analysis of variance (table 4) show significant differences between cutting periods (at vegetative, flowering and fruit growth) in number of stem branches and no significant differences between wheat straw covering treatments during both seasons autumn and spring. The number of stem branches varied between 60 in the 3 rd cutting and 122 in the 2 nd cutting, and between 97 in the 4th treatment and 111 in the 2 nd treatment during spring. And during autumn, the lowest branch number was in the 3rd cut 138 and the highest number was in the 2 nd cutting 170 with domination of autumn season compared to spring season.

\section{Leaf area:}

Table (4) illustrates analysis of variances between cutting periods and also between wheat straw treatments as regards millet leaf area. The results showed significant differences between cuttings, and no significant differences between treatments during both seasons. The highest leaf area was attained in 2nd cutting with $557 \mathrm{~cm} 2$ and the lowest LA was in the 3rd cutting with $238 \mathrm{~cm} 2$ during spring, and between $242 \mathrm{~cm} 2$ in the 1 st cutting and $945 \mathrm{~cm} 2$ in the 2 nd cutting during autumn season. And the treatment with the highest LA was the $3 \mathrm{rd}$ treatment with $414 \mathrm{~cm} 2$ and with the lowest LA was the 4th with $377 \mathrm{~cm} 2$ during spring with no significant differences between them. For spring season the treatment with the highest LA was the 4th (30 t/ ha) giving $669 \mathrm{~cm} 2$, and that with the lowest LA was the 2nd (10 t/ ha) with536 $\mathrm{cm} 2$ with no significant differences between treatments (table 4). 
TABLE (3): ANALYSIS OF VARIANCE OF PLANT HEIGHT, NUMBER OF BRANCHES AND LEAF AREA UNDER WHEAT STRAW MULCH TREATMENTS AND GROWTH STAGES OF MILLET DURING SPRING AND AUTUMN SEASONS 2009

\begin{tabular}{|c|c|c|c|c|c|}
\hline Source of variation & Replicate & growth stages & mulch treatments & GS x treatment & Error \\
\hline Plant height $(\mathbf{c m})$ & 1388 & $33440^{* *}$ & $2322^{* *}$ & $4489^{*}$ & 780 \\
\hline Number of branches & 2081 & $19144^{* *}$ & 759 & 583 \\
\hline Leaf area (cm2) & 30112 & $408397^{* *}$ & 8302 & 6030 \\
\hline
\end{tabular}

NS: Not significant at $\mathrm{P} \leq 0.05$

* : significant at $\mathrm{P} \leq 0.05$

** : significant at $\mathrm{P} \leq 0.01$

TABLE (4): MEANS OF PLANT HEIGHT, NUMBER OF BRANCHES AND LEAF AREA UNDER WHEAT STRAW MULCH TREATMENTS AND GROWTH STAGES OF MILLET DURING SPRING AND AUTUMN SEASONS 2009.

\begin{tabular}{|c|c|c|c|c|c|c|c|c|c|c|}
\hline \multirow{2}{*}{$\begin{array}{l}\text { Source of } \\
\text { variation }\end{array}$} & \multirow[t]{2}{*}{ season } & \multicolumn{4}{|c|}{ growth stages } & \multicolumn{5}{|c|}{ Wheat straw mulch treatments } \\
\hline & & $1 \mathrm{st}$ & 2nd & 3rd & LCD & $1 \mathrm{st}$ & 2nd & 3 rd & 4 th & $\mathrm{LCD}$ \\
\hline \multirow{2}{*}{$\begin{array}{c}\text { Plant } \\
\text { height } \\
(\mathrm{cm})\end{array}$} & spring & $98 \mathrm{c}$ & $165 \mathrm{~b}$ & $186 \mathrm{a}$ & 15 & $129 \mathrm{~b}$ & $160 \mathrm{a}$ & $151 \mathrm{a}$ & $156 \mathrm{a}$ & 17 \\
\hline & autumn & $140 \mathrm{c}$ & $181 \mathrm{~b}$ & $210 \mathrm{a}$ & 9 & $178 \mathrm{ab}$ & $210 \mathrm{a}$ & $168 \mathrm{~b}$ & $175 \mathrm{~b}$ & 11 \\
\hline \multirow{2}{*}{$\begin{array}{c}\text { Number } \\
\text { of } \\
\text { branches }\end{array}$} & spring & $118 \mathrm{a}$ & $122 \mathrm{a}$ & $60 \mathrm{~b}$ & 17 & $93 \mathrm{a}$ & $111 \mathrm{a}$ & $99 \mathrm{a}$ & $97 \mathrm{a}$ & 14 \\
\hline & autum & $156 \mathrm{ab}$ & $170 \mathrm{a}$ & $134 \mathrm{~b}$ & 22 & $145 \mathrm{a}$ & $156 \mathrm{a}$ & $148 \mathrm{a}$ & $150 \mathrm{a}$ & 16 \\
\hline \multirow[t]{2}{*}{ LA (cm2) } & spring & $376 \mathrm{~b}$ & $557 \mathrm{a}$ & $238 \mathrm{c}$ & 51 & $360 \mathrm{a}$ & $410 \mathrm{a}$ & $414 \mathrm{a}$ & $377 \mathrm{a}$ & 59 \\
\hline & autum & $242 c$ & $945 \mathrm{a}$ & $632 \mathrm{~b}$ & 116 & $582 \mathrm{a}$ & $536 \mathrm{a}$ & $641 \mathrm{a}$ & $669 \mathrm{a}$ & 134 \\
\hline
\end{tabular}

* Means followed by the same letter are not significantly different according to LSD at $\mathrm{P} \leq 0.05$

Fresh weight of millet plants:

Stem, leaves and total fresh weight:

Analysis of variance results.

Table (5) illustrates significant differences between cutting periods, and also between wheat straw treatments as regards stem fresh weight during both spring and autumn seasons. For leaves and total fresh weight there are significant differences between cuttings and also between treatments during spring season, but in autumn there are significant differences between cutting periods and no significant differences between treatments.

Means of fresh weight of stem, leaves and total fresh weight: Stem fresh weight

The average stem fresh weight ranged between $0.200 \mathrm{~kg} / \mathrm{m} 2$ in the 1 st cutting and $4.262 \mathrm{~kg} / \mathrm{m} 2$ in the second cutting during spring, and between $2.392 \mathrm{~kg} / \mathrm{m} 2$ in the 2 nd cutting and $4.481 \mathrm{~kg} / \mathrm{m} 2$ in the 3 rd cutting during autumn season with domination of autumn season in stem fresh weight compared to spring season (table 6). As for wheat straw treatments the lowest stem fresh weight during spring was attained in the 1 st treatment with $2645 \mathrm{~kg} / \mathrm{m} 2$ and the highest stem fresh weight was $3.725 \mathrm{~kg} / \mathrm{m} 2$ during the 4th treatment, and during autumn seasons the lowest stem fresh weight was $3.077 \mathrm{~kg} / \mathrm{m} 2$ during 2nd treatment and the highest was $3.720 \mathrm{~kg} / \mathrm{m} 2$ in the 1 st treatment with domination of autumn season in stem fresh weight compared to spring season (table 6).

Leaves fresh weight:
The mean values (table 6) of leaves fresh weight show that the lowest fresh weight is in the 1 st cutting $1.481 \mathrm{~kg} / \mathrm{m} 2$ and the highest is in the 2nd cutting $2.440 \mathrm{~kg} / \mathrm{m} 2$ during spring, while during autumn season the lowest leaves fresh weight is $1.678 \mathrm{~kg} / \mathrm{m} 2$ in the $3 \mathrm{rd}$ cutting and the highest is $5.650 \mathrm{~kg} /$ $\mathrm{m} 2$ during the 2 nd cutting with domination of autumn season. For the treatments the the lowest leave fresh weight is 1.695 $\mathrm{kg} / \mathrm{m} 2$ in the $3 \mathrm{rd}$ treatment ( $20 \mathrm{t} / \mathrm{ha}$ ) and the highest value is $2.041 \mathrm{~kg} / \mathrm{m} 2$ in the $1 \mathrm{st}$ treatment $(0.00 \mathrm{t} / \mathrm{ha})$ with no significant differences between treatments 1,2 and 4 during spring, while during autumn the lowest leaves fresh weight is $2.883 \mathrm{~kg} / \mathrm{m} 2$ in the $3 \mathrm{rd}$ treatment and the highest is $3.166 \mathrm{~kg}$ / $\mathrm{m} 2$ in the 2 nd treatment with no significant differences between the treatments.

Total fresh weight:

The mean values (table 6) of total millet fresh weight show that the lowest fresh weight is in the 1 st cutting $3706 \mathrm{~kg} / \mathrm{m} 2$ and the highest is in the $3 \mathrm{rd}$ cutting $6871 \mathrm{~kg} / \mathrm{m} 2$ during spring, while during autumn season the lowest total fresh weight is $4.975 \mathrm{~kg} / \mathrm{m} 2$ in the 1 st cutting and the highest is $8.318 \mathrm{~kg} / \mathrm{m} 2$ during the 2 nd cutting with domination of autumn season. For the treatments the lowest total fresh weight is $4.820 \mathrm{~kg} / \mathrm{m} 2$ in the 1 st treatment ( $20 \mathrm{t} / \mathrm{ha})$ and the highest value is $6.045 \mathrm{~kg} / \mathrm{m} 2$ in the 4 th treatment $(30 \mathrm{t} / \mathrm{ha}$ ) with no significant differences between treatments 1,2 and 3 during spring, while during autumn the lowest total fresh weight is $6183 \mathrm{~kg} / \mathrm{m} 2$ in the $3 \mathrm{rd}$ treatment and the highest is $6.891 \mathrm{~kg} / \mathrm{m} 2$ in the 1 st treatment with no significant differences between the 4 treatments.

TABLE (5): ANALYSIS OF VARIANCE OF STEM FRESH WT., LEAVES FRESH WT. AND TOTAL FRESH WT. UNDER WHEAT STRAW MULCH TREATMENTS AND GROWTH STAGES OF MILLET DURING SPRING AND AUTUMN SEASONS 2009.

\begin{tabular}{|l|l|l|l|l|l|}
\hline $\begin{array}{l}\text { Source of } \\
\text { variation }\end{array}$ & Replicate & growth stages & mulch treatments & GS x treatment & Error \\
\hline $\begin{array}{l}\text { Stem fresh wt. } \\
\text { (kg/m2) }\end{array}$ & $679635 \mathrm{NS}$ & $204874^{* *}$ & $243107^{* *}$ & $612482 \mathrm{NS}$ & 835700 \\
\hline $\begin{array}{l}\text { Leaves fresh wt. } \\
\text { (kg/m2) }\end{array}$ & $70924 \mathrm{NS}$ & $370658^{* *}$ & $321102^{*}$ & $769331^{* *}$ & 109969 \\
\hline $\begin{array}{l}\text { Total fresh wt. . } \\
\text { (kg/m2) }\end{array}$ & $1070138 \mathrm{NS}$ & $10095677^{* *}$ & $3633472^{*}$ & $2645607^{*}$ & 774340 \\
\hline
\end{tabular}


NS: Not significant at $\mathrm{P} \leq 0.05$

$*$ : significant at $\mathrm{P} \leq 0.05$

** : significant at $\mathrm{P} \leq 0.01$

TABLE (6): MEANS OF STEM FRESH WT., LEAVES FRESH WT. AND TOTAL FRESH WT. UNDER WHEAT STRAW MULCH TREATMENTS AND GROWTH STAGES OF MILLET DURING SPRING AND AUTUMN SEASONS 2009.

\begin{tabular}{|c|c|c|c|c|c|c|c|c|c|c|}
\hline \multirow{2}{*}{$\begin{array}{l}\text { Source of } \\
\text { variation }\end{array}$} & \multirow[t]{2}{*}{ season } & \multicolumn{4}{|c|}{ growth stages } & \multicolumn{5}{|c|}{ Wheat straw mulch treatments } \\
\hline & & 1st & 2nd & 3rd & LCD & 1st & 2nd & 3rd & 4th & LCD \\
\hline \multirow{2}{*}{$\begin{array}{l}\text { Stem } \\
\text { fresh wt. } \\
(\mathrm{kg} / \mathrm{m} 2)\end{array}$} & spring & $2.00 \mathrm{c}$ & $4.262 \mathrm{a}$ & $3.178 \mathrm{~b}$ & 0.663 & $2.645 \mathrm{~b}$ & $3.187 \mathrm{~b}$ & $3.029 \mathrm{~b}$ & $3.725 \mathrm{a}$ & 0.765 \\
\hline & autum & $3.021 \mathrm{~b}$ & $2.392 \mathrm{a}$ & $4.481 \mathrm{a}$ & 0.438 & $3.720 \mathrm{a}$ & $3.077 \mathrm{~b}$ & $3.079 \mathrm{~b}$ & $3.316 \mathrm{a}$ & 0.506 \\
\hline \multirow{2}{*}{$\begin{array}{l}\text { Leaves } \\
\text { fresh wt. . } \\
(\mathrm{kg} / \mathrm{m} 2)\end{array}$} & spring & $1.481 \mathrm{c}$ & $2.440 \mathrm{a}$ & $1.892 \mathrm{~b}$ & 0.240 & $2.041 \mathrm{a}$ & $1.989 \mathrm{a}$ & $1.695 \mathrm{~b}$ & $2.026 \mathrm{a}$ & 0.277 \\
\hline & autum & $1.753 \mathrm{~b}$ & $5.650 \mathrm{a}$ & $1.678 \mathrm{~b}$ & 0.41 & $2.995 \mathrm{a}$ & $3.166 \mathrm{a}$ & $2.883 \mathrm{a}$ & $3.062 \mathrm{a}$ & $0 . .542$ \\
\hline \multirow{2}{*}{$\begin{array}{l}\text { Total } \\
\text { fresh wt. . } \\
(\mathrm{kg} / \mathrm{m} 2)\end{array}$} & spring & $3.706 \mathrm{c}$ & $3.871 \mathrm{a}$ & $5.334 \mathrm{~b}$ & 0.716 & $4.820 \mathrm{~b}$ & $5.366 \mathrm{~b}$ & $4.975 \mathrm{~b}$ & $6.095 \mathrm{a}$ & 0.826 \\
\hline & autum & $4.975 \mathrm{c}$ & $8.318 \mathrm{a}$ & $6.143 \mathrm{~b}$ & 0.797 & $6.891 \mathrm{a}$ & $6.500 \mathrm{a}$ & $6.183 \mathrm{a}$ & $6.341 \mathrm{a}$ & 0.921 \\
\hline
\end{tabular}

* Means followed by the same letter are not significantly different according to LSD at $\mathrm{P} \leq 0.05$

Dry weight of millet plants:

Stem, leaves and total dry weight:

Analysis of variance results:

Table (7) illustrates significant differences between cutting periods, and no significant differences between wheat straw treatments as regards stem and total millet dry weight during both spring and autumn seasons. For leaves dry weight there is no significant differences between cuttings and also between treatments during both season.

Means of fresh weight of stem, leaves and total dry weight: Stem dry weight

The average stem dry weight ranged between $0.578 \mathrm{~kg} / \mathrm{m} 2$ in the 1 st cutting and $1.196 \mathrm{~kg} / \mathrm{m} 2$ in the 3 rd cutting during spring, and between $0.268 \mathrm{~kg} / \mathrm{m} 2$ in the $1 \mathrm{st}$ cutting and $1.612 \mathrm{~kg} / \mathrm{m} 2$ in the $2 \mathrm{nd}$ cutting during autumn season with domination of autumn season in stem dry weight compared to spring season (table 8). As for wheat straw treatments the lowest stem dry weight during spring was attained in the 1st treatment with $0.792 \mathrm{~kg} / \mathrm{m} 2$ and the highest stem dry weight was $0.998 \mathrm{~kg} / \mathrm{m} 2$ during the 4th treatment, and during autumn seasons the lowest stem dry weight was $0.928 \mathrm{~kg} /$ $\mathrm{m} 2$ during $3 \mathrm{rd}$ treatment and the highest was $1.071 \mathrm{~kg} / \mathrm{m} 2$ in the 1st treatment with no significant differences between treatments in both seasons, with domination of autumn season in stem dry weight compared to spring season (table 8).

\section{Leaves dry weight:}

The mean values (table 8) of leaves dry weight show that the lowest dry weight is in the 1 st cutting $0.446 \mathrm{~kg} / \mathrm{m} 2$ and the highest is in the $3 \mathrm{rd}$ cutting $0.550 \mathrm{~kg} / \mathrm{m} 2$ during spring, while during autumn season the lowest leaves dry weight is $0.410 \mathrm{~kg} / \mathrm{m} 2$ in the $3 \mathrm{rd}$ cutting and the highest is $0.559 \mathrm{~kg} /$ $\mathrm{m} 2$ during the 2 nd cutting with significant differences between cuttings in both seasons, with domination of autumn season. For the treatments the lowest leave dry weight is $0.459 \mathrm{~kg} / \mathrm{m} 2$ in the $1 \mathrm{st}$ treatment $(0.00 \mathrm{t} / \mathrm{ha})$ and the highest value is $0.540 \mathrm{~kg} / \mathrm{m} 2$ in the 2 nd treatment ( $20 \mathrm{t} / \mathrm{ha}$ ) with no significant differences between treatments during spring, while during autumn the lowest leaves dry weight is $0.443 \mathrm{~kg}$ / $\mathrm{m} 2$ in the 4th treatment and the highest is $0.540 \mathrm{~kg} / \mathrm{m} 2 \mathrm{in}$ the 1 st treatment with no significant differences between treatments during autumn, with domination of autumn to spring.

Total fresh weight:

The mean values (table 8) of total millet dry weight show that the lowest dry weight is in the 1 st cutting $1.024 \mathrm{~kg} / \mathrm{m} 2$ and the highest is in the $3 \mathrm{rd}$ cutting $1.746 \mathrm{~kg} / \mathrm{m} 2$ during spring, while during autumn season the lowest total dry weight is $0.761 \mathrm{~kg} / \mathrm{m} 2$ in the 1 st cutting and the highest is $2.170 \mathrm{~kg} /$ $\mathrm{m} 2$ during the $2 \mathrm{nd}(10 \mathrm{t} / \mathrm{ha})$ cutting with domination of autumn season. For the treatments the lowest total dry weight is $1.251 \mathrm{~kg} / \mathrm{m} 2$ in the $1 \mathrm{st}$ treatment $(0.00 \mathrm{t} / \mathrm{ha})$ and the highest value is $1.521 \mathrm{~kg} / \mathrm{m} 2$ in the 4th treatment (30 t/ ha) with no significant differences between treatments during spring, while during autumn the lowest total dry weight is $1.385 \mathrm{~kg} / \mathrm{m} 2$ in the $3 \mathrm{rd}$ treatment $(20 \mathrm{t} / \mathrm{ha})$ and the highest is $1.611 \mathrm{~kg} / \mathrm{m} 2$ in the $1 \mathrm{st}$ treatment with no significant differences between the 4 treatments.

TABLE (7): ANALYSIS OF VARIANCE OF STEM DRY WT., LEAVES DRY WT. AND TOTAL DRY WT. UNDER WHEAT STRAW MULCH TREATMENTS AND GROWTH STAGES OF MILLET DURING SPRING AND AUTUMN SEASONS 2009.

\begin{tabular}{|l|l|l|l|l|l|}
\hline $\begin{array}{l}\text { Source of } \\
\text { variation }\end{array}$ & Replicate & growth stages & mulch treatments & GS x treatment & Error \\
\hline $\begin{array}{l}\text { Stem dry wt. } \\
\text { (kg/m2) }\end{array}$ & $60673 \mathrm{NS}$ & $1530135^{* * *}$ & $89266 \mathrm{NS}$ & $87649 \mathrm{NS}$ & 15839 \\
\hline $\begin{array}{l}\text { Leaves dry wt. } \\
\text { (kg/m2) }\end{array}$ & $16018 \mathrm{NS}$ & $43406 \mathrm{NS}$ & $18084 \mathrm{NS}$ & $29836 \mathrm{NS}$ & 17912 \\
\hline $\begin{array}{l}\text { Total dry wt. } \\
\text { (kg/m2) }\end{array}$ & $110529 \mathrm{NS}$ & $86313^{* * *}$ & $163923 \mathrm{NS}$ & $15855 \mathrm{NS}$ & 135812 \\
\hline
\end{tabular}

NS: Not significant at $\mathrm{P} \leq 0.05$

$*$ : significant at $\mathrm{P} \leq 0.05$

** : significant at $\mathrm{P} \leq 0.01$ 
TABLE (8): MEANS OF STEM DRY WT., LEAVES DRY WT. AND TOTAL DRY WT. UNDER WHEAT STRAW MULCH TREATMENTS AND GROWTH STAGES OF MILLET DURING SPRING AND AUTUMN SEASONS 2009

\begin{tabular}{|c|c|c|c|c|c|c|c|c|c|c|}
\hline \multirow{2}{*}{$\begin{array}{l}\text { Source of } \\
\text { variation }\end{array}$} & \multirow[t]{2}{*}{ season } & \multicolumn{4}{|c|}{ growth stages } & \multicolumn{5}{|c|}{ Wheat straw mulch treatments } \\
\hline & & $1 \mathrm{st}$ & 2nd & $3 \mathrm{rd}$ & LCD & $1 \mathrm{st}$ & 2nd & $3 r d$ & 4th & LCD \\
\hline \multirow{2}{*}{$\begin{array}{c}\text { Stem dry } \\
\text { wt. } \\
(\mathrm{kg} / \mathrm{m} 2)\end{array}$} & spring & $0.578 \mathrm{c}$ & $0.890 \mathrm{~b}$ & $1.196 \mathrm{a}$ & 0.224 & $0.792 \mathrm{a}$ & $0.903 \mathrm{a}$ & $0.860 \mathrm{a}$ & $0.998 \mathrm{a}$ & 0.259 \\
\hline & autumn & $0.268 \mathrm{c}$ & $1.612 \mathrm{a}$ & $1.180 \mathrm{~b}$ & 0.224 & $1.071 \mathrm{a}$ & $1.022 \mathrm{a}$ & $0.928 \mathrm{a}$ & $1.059 \mathrm{a}$ & 0.258 \\
\hline \multirow{2}{*}{$\begin{array}{c}\text { Leaves } \\
\text { dry wt. . } \\
\text { (kg/m2) }\end{array}$} & spring & $0.446 \mathrm{~b}$ & $489 \mathrm{ab}$ & $550 \mathrm{a}$ & 97 & $459 \mathrm{a}$ & $540 \mathrm{a}$ & $466 \mathrm{a}$ & $516 \mathrm{a}$ & 0.112 \\
\hline & autumn & $493 \mathrm{ab}$ & $0.559 \mathrm{a}$ & $0.410 \mathrm{~b}$ & 0.112 & $0.540 \mathrm{a}$ & $0.509 \mathrm{a}$ & $0.475 \mathrm{a}$ & $0.443 \mathrm{a}$ & 0.129 \\
\hline \multirow{2}{*}{$\begin{array}{c}\text { Total dry } \\
\text { wt. . } \\
(\mathrm{kg} / \mathrm{m} 2)\end{array}$} & spring & $1.024 \mathrm{c}$ & $1.379 \mathrm{~b}$ & $1.746 \mathrm{a}$ & 0.256 & $1.251 \mathrm{a}$ & $1.443 \mathrm{a}$ & $1.326 \mathrm{a}$ & $1.521 \mathrm{a}$ & 0.308 \\
\hline & autumn & $0.761 \mathrm{c}$ & $2.170 \mathrm{a}$ & $1.590 \mathrm{~b}$ & 0.279 & $1.611 \mathrm{a}$ & $1.531 \mathrm{a}$ & $1.385 \mathrm{a}$ & $1.502 \mathrm{a}$ & 0.322 \\
\hline
\end{tabular}

* Means followed by the same letter are not significantly different according to LSD at $\mathrm{P} \leq 0.05$

\section{DISCUSSION}

The results illustrate that millet yield of fresh weight reached $3.706,6.872$ and $5.334 \mathrm{~kg} / \mathrm{m} 2$ for cuttings during vegetative growth, flowering stage and fruit stage during spring, and in autumn it reached $4.975,8.308$ and $6.143 \mathrm{~kg} \mathrm{/} \mathrm{m2}$ respectively during the three stages. The average millet dry weight reached 1.024, 1.379, $1.746 \mathrm{~kg} / \mathrm{m} 2$ during spring and $0.761,2.170,1.590 \mathrm{~kg} / \mathrm{m} 2$ in autumn during the three growth stages respectively. The results indicate that the highest fresh and dry millet weight occurred during flowering stage (2nd cutting period) and that autumn is more favorable to spring in millet growth, and this may be due to differences in temperature and its role in participation of accumulation of the dry matter inside the plants during the different plant growth stages. Leaves participation in dry weight reached $64.8 \%, 25.8 \%$ and $25.9 \%$ in the three growth stages during autumn compared to $35.2,74.2$ and $74 \%$ for the stem, and this high percentage of leaves during vegetative stage in this season might be due to low temperature during the first weeks of plant life thus encouraging more leaf growth. In the previous studies carried out by Badaruddin, et al. (1999) in Mucsico yield improved by $(11 \%)$ under soil mulching with plant straw during hot spring season compared to cold winter, and this agrees with the present results where there is increases in the biomass and its components during autumn compared to spring. The results also indicated that covering soil with wheat straw positively affected plant height, number of stem branches and fresh weight of leaves and total fresh weight during spring. The 2 nd treatment (10 t/ ha) proved to be more effective than the others, thus giving the highest plant height, number of branches and total leaves fresh weight. On the other hand the 4th treatment ( $30 \mathrm{t} / \mathrm{ha}$ ) was more effective compared to other treatments and gave the highest total plant fresh weight. For the plant dry weight the highest stem, leaves and total dry weight during spring occurred in the 3rd cutting period (fruit stage), and during autumn in the 2nd cutting (flowering stage). Zhang et al. 2015 used three straw mulch rates; 3, 6 and $9 \mathrm{t} /$ ha on growth of winter wheat (Triticum aestivum), they found water content in the $0-200 \mathrm{~cm}$ soil layer increased significantly by $0.7-22.5 \%$, WUE by $30.6 \%$, and yield by $13.3-23.0 \%$ compared to unmulched soil. Covering the soil with wheat straw showed no positive effects on increasing total millet dry weight and its components stem and leaves during all plant growth stages. It can be seen that mulching the soil with wheat straw positively and significantly affected millet plant height, number of stem branches, leaf area and total dry weight and its components, and also positively affected total plant fresh weight and its components stem and leaves but with no significant differences between treatments $(0,10,20$, $30 \mathrm{t} / \mathrm{ha}$ ). The results obtained in this study agree with other research results documented by others. van Donk et al. (2008) found significant increase in corn yield by $12.4 \mathrm{Mg}$ ha-1 in the residue-covered plots, than the bare-soil plots. Sinkevičienè et al. (2009) found mulching with peat or sawdust significantly decreased soil temperature, and significantly raised soil moisture content throughout the experimental period. They also noticed higher amount of available phosphorus in the mulched soil plots, and also available potassium in the soil covered with grass. Ji \& Unger, (2001; Kar \& Kumar, (2007) detected reduction in evaporation by covering soil with plant residues, and also soil temperature will be stable. On the other hand some researchers found that mulching at some amounts can have negative effects, and reduces yield production (Gao and $\mathrm{Li}$, 2005). Wicks et al.(1994) suggested that the crop yield is only increased with mulch amounts within certain ranges. Cook et al.(2006) found wheat straw mulch at a rate of 2000$4000 \mathrm{~kg}$ ha-1 increased the maize yield, whereas a straw mulch of $6000-8000 \mathrm{~kg}$ ha-1 greatly decreased maize production.

\section{CONCLUSION}

The result of this study indicated significant differences between the different cutting periods in all millet plant parameters studied during spring and autumn seasons. As for wheat straw covering treatments the results showed significant differences in the total millet fresh weight and its components stem and leaves in addition to plant height during spring, but for autumn season the results indicated significant differences between treatments in stem fresh weight and plant height. There is also significant interaction between cuttings and treatments for the total fresh weight, fresh weight of leaves and plant height during spring, with no significant interaction between cuttings and treatments during autumn season. 


\section{REFERENCE}

[1] D. Bilalis, N. Sidiras, G. Economou, C. Vakali. "Effect of different levels of wheat straw soil surface coverage on weed flora in Vicia faba crops". J. Agron. Crop Sci. 189, 233 - 241. 2002.

[2] H. F. Cook, G. S. Valdes, H. C. Lee. "Mulch effects on rainfall interception, soil physical characteristics and temperature under Zea mays L. Soil Till”. Res. 91, 227-235. 2006.

[3] T. Döring, M. Brandt, J. Heß, M. Finckh, H. Saucke.. "Effect of straw mulch on soil nitrate dynamics, weeds, yield and soil erosion in organically grown potates". Field Crops Res. Article in press. ScienceDirect, 2-10. 2005.

[4] S. Gruber, D. Achraya, W. Claupein. "Wood chips used for weed control in Organic Farming". J. Plant Dis. Protect. Special issue XXI, 401-406. 2008.

[5] M. A. Hares, M. D. Novak. "Simulation of surface energy balance and soil temperature under strip tillage: II. Field test". Soil Sci. Soc. Am. J. 56, 29-36. 1992.

[6] S. Ji, P.W. Unger. "Soil water accumulation under different precipitation, potential evaporation and straw mulch conditions". Soil Sci. Soc. Am. J. 65, 442-448. 2001.

[7] D. Jodaugienė, R. Pupalienė, M. V. Urbonienė, V. Pranckietis, I. Pranckietienè. "The impact of different types of organic mulches on weed emergence". Agron. Res. 4, 197-200. 2006.

[8] G. Kar, A. Kumar. "Effects of irrigation and straw mulch on water use and tuber yield of potato in eastern India". J. Agricult.l Water Manag. 94(109), 116. 491. 2007.

[9] L. Radics, E. S. Bognar. "Comparison of different methods of weed control in organic green bean and tomato". Acta Hort. 638, 189196. 2004.

[10] R.R. Sharma, V.P. Sharma. "Mulch influences fruit growth, albinism and fruit quality in strawberry (Fragaria $x$ ananassa Duch.)".Fruits 58, 221-227. 2003..

[11] R.S. Singh, R.R. Sharma, R.K. Goyal. "Interacting effects of planting time and mulching on "Chandeler" strawberry (Fragaria $\mathrm{x}$ ananassa Duch.)". Sci. Hortic. 111, 344- 351. 2007.

[12] A.D. Sinkevičienė, R. Jodaugienè, M. Pupalienė, M. Urbonienè.. The influence of organic mulches on soil properties and crop yield. Agronomy Research 7(Special issue I), 485-491. 2009.

[13] A. Sǿnsteby, A. Nes, F. Måge, "Effects of bark mulch and NPK fertilizer on yield, leaf nutrien status and soil mineral nitrogen during three years of strawberry production. Acta. Agric. Scand. Sect. B, Soil and Plant 54, 128 - 13. 2004.

[14] P.W. Unger. "Straw-mulch rate effect on soil water storage and sorghum yield". Soil Sci. Soc. Am. J. 42, 486-491. 1978

[15] S. J. Van Donk, D. L. Martin, S. Irmak, S. R. Melvin, J. L. Petersen, D. R. Davison. "Crop residue cover effects on evaporation, soil water content, and yield of deficit-irrigated corn in west-central Nebraska". Transactions of the ASABE, 53(6), 1787-1797. 2010.

[16] G.A. Wicks, D.A. Crutchfield, O.C. Burnside. "Influence of wheat (Triticum aestivum) straw mulch and metolachlor on corn (Zea mays) growth and yield". Weed Sci. 42, 141-147. 1994.

[17] Z. Peng, T. Wang, H. Wang, M. Wang, X. Meng, S. Mou, R. Zhang, J. Zhikuan, H. Qingfang. "Effects of straw mulch on soil water and winter wheat production in dryland". Scientific Reports, $5,10725,2015$

[18] J. Zhao, Z. Xu. "North China water development and utilization of dryland cropland". Ch. 2. 51-55 (China Agriculture Press, Beijing). (In Chinese). 1996. 